BULLETIN Bulletin hispanique

HispaniquE Université Michel de Montaigne Bordeaux

109-2 | 2007

La formation du Parnasse espagnol XVe-XVIII ${ }^{\mathrm{e}}$ siècle

\title{
Los poetas del Siglo de Oro en textos escolares (Siglos XVII-XVIII)
}

Inmaculada Osuna

\section{(2) OpenEdition}

Journals

Edición electrónica

URL: http://journals.openedition.org/bulletinhispanique/340

DOI: 10.4000/bulletinhispanique.340

ISSN: 1775-3821

Editor

Presses universitaires de Bordeaux

Edición impresa

Fecha de publicación: 1 diciembre 2007

Paginación: 615-642

ISBN: 978-2-85276-096-7

ISSN: 0007-4640

\section{Referencia electrónica}

Inmaculada Osuna, "Los poetas del Siglo de Oro en textos escolares (Siglos XVII-XVIII) », Bulletin hispanique [En línea], 109-2 | 2007, documento 12, Publicado el 01 diciembre 2010, consultado el 30 abril 2019. URL : http://journals.openedition.org/bulletinhispanique/340 ; DOI : 10.4000/ bulletinhispanique.340 


\title{
Los poetas del Siglo de Oro en textos escolares (Siglos XVII-XVIII)
}

\author{
INMACULADA Osuna \\ Universidad Complutense de Madrid ${ }^{1}$
}

Aux XVII et XVIII siècles, en dépit du prestige académique de la culture latine, il est fait peu à peu mention des poètes espagnols dans les textes scolaires. Pour ce qui est du XVII siècle, les témoignages sporadiques rencontrés ont généralement trait à la Métrique. Au XVIII siècle, le processus sintensifie et se manifeste dans les ouvrages imprimés de plus ample diffusion : "exercices littéraires" ou "examens publics" et manuels, particulièrement de Poétique, et, plus rarement, de Rhétorique et de Grammaire.

En los siglos XVII y XVIII, pese al contexto de prestigio académico de la cultura latina, la mención de poetas españoles se infiltra poco a poco en textos escolares. Para el siglo XVII, los esporádicos testimonios hallados suelen estar relacionados con la Métrica. En el siglo XVIII, el proceso se intensifica y puede detectarse en materiales impresos de mayor difusión: «ejercicios literarios» o "exámenes públicos» y manuales, especialmente de Poética, y también, con menor frecuencia, de Retórica y de Gramática.

During the seventeenth and eighteenth centuries, Spanish poets, in spite of the academic prestige of Latin, started appearing -little by little- in scholastic texts. The scarce seventeenth-century examples are commonly related to metrical issues. The process heightened in the eighteenth century: names of Spanish poets can be found in widespread publications such as "literary exercises", "public examinations" and handbooks, specially of Poetics, but also of Grammar and Rhetoric.

Mots-clés: XVII ${ }^{e}-\mathrm{XVIII}{ }^{\mathrm{e}}$ - Textes scolaires - Poètes du Siècle d'Or - Critique littéraire.

1. Este trabajo se enmarca en líneas de investigación sobre Poesía del Siglo de Oro desarrolladas al amparo del Programa Ramón y Cajal (MEC) y del Proyecto de Investigación «La República de los poetas en los Siglos de Oro. Textos fundacionales» (HUM2004-02373/ FILO) (Dirección General de Investigación, MEC).

BHi, Tome 109, nº 2 - décembre 2007 - p. 615 à 642. 
$\mathrm{E}$ N 1612 el abogado e historiador Francisco Bermúdez de Pedraza publica un Arte legal para estudiar la jurisprudencia. La naturaleza de la materia no obsta para que la poesía, aunque marginal, reciba su pequeño espacio. Para el autor, el estudiante a ello inclinado no tiene por qué descartar la ocasional dedicación a este ejercicio, siempre que, en vez de versos obscenos o satíricos, se emplee en «algún poema honesto, alabando algún heroico varón, o singular virtud, o traduciendo en versos algunas leyes, o explicándol[a]s en ellos» ${ }^{2}$; además, el verso puede ser útil para formular preguntas de cuestiones problemáticas o alabar los méritos de doctores y jurisconsultos ${ }^{3}$. Con tales miras, y ya en el ámbito de la lectura, no es de extrañar que, casi al inicio del tratado, Bermúdez de Pedraza se acuerde de obras y autores adecuados para descansar algún rato de la jurisprudencia sin renunciar al provecho ${ }^{4}$. Tales recomendaciones incluyen la "historia divina y humana», por sus ejemplos de buen y mal gobierno y su utilidad para interpretar leyes, y para ello también sirven poetas como Virgilio y Homero, o filósofos como Platón y Aristóteles. Esta condescendencia hacia el ocio del estudiante se amplía aún más:

Y si dejando la historia quisiere poetas latinos, lustrará mucho la gravedad del verso de Virgilio, la facilidad de Ovidio, el donaire de Marcial y los conceptos de Séneca y Lucano. Y si de italianos, el Ariosto y el Tasso; si de españoles, Garcilaso, don Alonso de Ercilla, Silvestre, don Diego de Mendoza y Francisco de Aldana. De otros libros de entretenimiento encomiendo solos cuatro, que por vulgares no han de ser tenidos en poco: Celestina, Lazarillo de Tormes, primera parte de Diana y Floresta Española, que son argumento del ingenio, agudeza grave y donaire de la lengua y nación española; no se tenga por encarecimiento, sino al leerlos hagan alto en sus dichos y sentencias. (p. 43)

En la edición de 1633, incluso se preocupa de revisar la relación de autores y, en un curioso gesto de actualización, suma a la lista de poetas, sin identificarlo, a «nuestro famoso Español», tal vez en referencia a Góngora ${ }^{5}$.

2. Francisco Bermúdez de Pedraza, Arte legal para estudiar la jurisprudencia, Salamanca, Antonia Ramírez, a costa de Nicolás Martín del Castillo, 1612, p. 163.

3. Ibid., pp. 168-169.

4. Ibid., pp. 42-43.

5. Arte legal para el estudio de la jurisprudencia. Nuevamente corregido y añadido, Madrid, Francisco Martínez, 1633, p. 40. Me inclino por Góngora, frente a Lope de Vega, cuya celebridad se asocia de manera más inmediata al teatro que a la poesía lírica o épica, o al polifacético Quevedo, por varios motivos. En primer lugar, cabe preguntarse por qué alguien no recordado en 1612 merece este honor en 1633. Precisamente entre ambas fechas la resonancia de Góngora se ha agudizado con la polémica en torno a sus Soledades. Además, también se ha producido su muerte; no hay que olvidar que, aun no siendo un proceder 
Como puede apreciarse, al margen del inesperado contexto, la cita destaca, en primer lugar, por lo ajustado de una nómina en buena medida acorde con cánones largamente vigentes. La conjunción de literatura en latín y en lengua vulgar también resulta notable, aliñada, como lo está, con cierto toque apologético de la lengua nacional, por lo demás coherente con algunas de las razones expuestas en el prólogo en justificación de su decisión de no escribir el libro en latín ${ }^{6}$; con todo, no faltan los matices, pues si bien se citan más obras o autores modernos, de los latinos se detallan sus valores poéticos, posiblemente siguiendo estimaciones asentadas en medios académicos. La distinción entre la prosa, citada por obras y no por autores, y la poesía, identificada a partir de estos, quizás atiende a la multiplicidad creativa del género, pero no deja de ser curioso que el criterio autorial se mantenga aun en casos como Lucano y Ercilla, destacables por un poema singular. Por lo demás, frente a la valoración del contenido para la historia sagrada y profana, los parámetros ahora abarcan tanto conceptos, dichos y sentencias, sobre todo en obras en prosa, como los aspectos estilísticos detallados en poetas latinos, lo cual lleva al terreno de la retórica, aquí no enfatizado, pero que será fundamental en la aplicación escolar del canon poético.

El testimonio de Bermúdez de Pedraza se halla en un contexto «escolar» un tanto sui generis, pues su obra es más bien un instrumento complementario en comparación con los manuales, apuntes y lecciones plenamente integrados en la correspondiente disciplina académica. No es de descartar

unánime, algunos elencos de varones ilustres de la época prefieren mencionar solo a personas fallecidas, y que Bermúdez de Pedraza, frente a lo que hace en su Antigüedad y excelencias de Granada (1608) en un contexto de laus urbis, aquí no revela particular interés por incluir poetas vivos. A estos argumentos se pueden ańadir otros, tal vez más imprecisos: por ejemplo, la proximidad que el autor muestra, en los preliminares y en la nómina de poetas de su historia local, con el núcleo granadino de admiradores de Góngora; o el antecedente que ofrece otra elogiosa perífrasis elusiva en el título de la edición de Juan López de Vicuña, Obras en verso del Homero español (1627), perífrasis luego replicada con la de "Píndaro andaluz» en las Lecciones solemnes (1630) de José Pellicer.

6. «La una ser este libro así para los padres, que los menos saben la lengua latina, como para los hijos, que en su primera edad y principios de sus estudios no son todos consumados latinos [...]. La otra porque la lengua castellana no está como en los siglos pasados, corta de vocablos, grosera de palabras y circunscripta a Castilla, antes tan abundante y rica y tan llena de tropos y figuras, que no hay versión de lengua extrańa ni concepto tan interior nuestro, que no lo explique con propriedad y elegancia. Y no es menos general que la latina, pues sus preciosas monedas la tienen tan extendida por todas las naciones, que si todas no la hablan, por lo menos todas la entienden tan bien que ni por más universal ni por más elegante permitimos que la lengua castellana se rinda a la latina. Y la última, que todas las naciones escribieron las ciencias en su lengua y vulgar idioma [...], porque de esta suerte los discípulos entendían con más facilidad a sus maestros, y ellos enseñaban con la misma» (pp. 4-5). 
que sus declaraciones se estuvieran haciendo eco de una praxis no demasiado insólita en el momento; sin embargo, habría de pasar bastante tiempo antes de que la integración en la formación escolar de la literatura española, y más concretamente de la poesía, llegara a aflorar de manera sistemática en textos expresamente concebidos para un uso académico, a los que he pretendido ceñirme.

Hasta entrado el siglo XVIII el rastreo de materiales se torna arduo e incierto. Como es sabido, hasta el siglo XIX, la literatura, tal como hoy la entendemos, no forma parte de un currículum escolar generalizado ${ }^{7}$. Ni siquiera la Cátedra de Historia Literaria creada en 1786 en los Reales Estudios de San Isidro sirve de excepción, y no solo por su singularidad, su corta vigencia y las escasas expectativas de auditorio ${ }^{8}$. Aparte de estos factores circunstanciales, la amplitud de concepto en sus contenidos inevitablemente dejaría reducida la enseñanza de la literatura española, en el sentido actual del término. Baste recordar al respecto que la obra de referencia para la materia era la de Juan Andrés, Del origen, progreso y estado actual de toda la literatura, y que el primer curso se dedicó a la cultura de egipcios, griegos y romanos y el segundo a estudios bíblicos ${ }^{9}$.

Para los siglos anteriores, las dificultades para esclarecer la presencia real en las aulas de contenidos sobre poesía española radican, lógicamente, en la vigencia de una enseñanza marcada por la cultura en lengua latina, por mucho que el español vaya ganando terreno, entre otras causas por puro sentido práctico, a su vez, siempre más favorable al estudio lingüístico que al literario. De hecho, los contenidos literarios vernáculos consiguieron

7. Precisamente con respecto a dicho siglo, y en referencia a los «clásicos» españoles, centra su estudio Andrés Soria («La utilización de los clásicos en la enseñanza y especialmente en la Retórica (Bosquejo de aproximación)", Miscelánea de estudios dedicados al profesor Antonio Marin Ocete, Granada, Universidad de Granada, 1974, vol. II, pp. 1037-1063).

8. Aunque esta figuraba entre las obligaciones de primer bibliotecario desde unos años antes, no comenzó sus enseñanzas de manera regular hasta 1789; en 1802 se suprime (José Simón Díaz, Historia del Colegio Imperial de Madrid. Tomo II, Madrid, CSIC, 1959, pp. 125-134; otros datos de interés en Antonio Viñao, «Por un análisis socio-cultural de la élite intelectual y académica: los profesores y bibliotecarios de los Reales Estudios de San Isidro (1770-1808)", La Culture des Élites Espagnoles à l'Époque Moderne, Bulletin Hispanique, 97, 1 (1995), pp. 299-315). Son elocuentes las declaraciones de los mismos encargados de poner en marcha la Cátedra, Francisco Messeguer y Miguel de Manuel, en su «Método para la enseñanza de la Historia Literaria»: "[La materia] es enteramente voluntaria; porque no está en el número de aquellas Ciencias que forman lo que se llama Carrera literaria y cuyos Cursos se necesitan para los honores y más efectos académicos; no se pueden esperar en ella más oyentes que los que traerá la curiosidad, o tal vez la diversión» (cit. por José Simón Díaz, op. cit., p. 127).

9. José Simón Díaz, op. cit., pp. 127 y 131-132. 
infiltrarse por dos vías, según las disciplinas: la asimilación -pero por mucho tiempo con tratamiento subordinado- a conocimientos de lengua latina y el aprovechamiento de espacios propios que la remisión al latín no podía cubrir.

Este último motivo sustenta los testimonios más explícitos que abordaré para el siglo XVII, referentes a Métrica, espacio donde, frente a la Retórica, la transposición desde el latín resultaba inviable, como ya indicara Juan Díaz Rengifo al justificar su Arte poética española ${ }^{10}$. Si la práctica de la poesía vernácula tenía cabida en la vida escolar, lógicamente también deberían tenerla las nociones métricas, al menos cuando el ejercicio poético se muestra tan extendido entre los alumnos como para no atribuirlo a casos excepcionales de aprendizaje en otros contextos; con todo, es difícil aventurar en qué medida esas necesarias nociones métricas llegaron a estar acompañadas de una nómina de potenciales autoridades, y más aún de un bosquejo de historia literaria. Problema aparte es dilucidar por qué y en qué medida el ámbito académico asumió desde dentro, desde la propia vida oficial, esa práctica poética no solo latina, sino también vernácula. Sin pretender abordar en su complejidad la cuestión, quizás quepa postular el paso desde la ejercitación de conocimientos poéticos y retóricos latinos, intrínsecos al currículum escolar, hasta una marginal presencia de la poesía vernácula en actos públicos; el deseo de mayor visibilidad social y la ampliación a un público potencial no inmerso en la cultura latina (padres, benefactores, autoridades civiles, etc.) facilitarían, al menos en tales actos, cada vez mayor proporción y diversidad en la presencia de poesía vernácula, lo cual debería estar acompañado de algún tipo de adiestramiento dirigido por los docentes.

La tradición escolar de poesía para certámenes, exposición mural, recibimientos y celebraciones varias está arraigada en ciertas ciudades ya en el siglo XVI, y solo la eclosión urbana de tales manifestaciones en el XVII, con la pareja marginación del latín, desdibuja en buena medida esa vinculación académica ${ }^{11}$. Por lo demás, a lo largo del XVII, las aportaciones de centros jesuitas a fiestas públicas y colegiales documentan el estímulo a

10. «Porque ni juzgo ser suficiente para la poesía espańola todo lo que se aprende en las escuelas, donde se enseña la cuantidad de la sílaba latina, ni temo la diversidad de pareceres», en la dedicatoria al Conde de Monterrey (Juan Díaz Rengifo, Arte poética española, Madrid, Juan de la Cuesta, 1606, h. 4v).

11. Véase, por ejemplo, José Simón Díaz, «La poesía mural, su proyección en Universidades y Colegios», en Estudios sobre el Siglo de Oro. Homenaje al profesor Francisco Ynduráin, Madrid, Editora Nacional, 1984, pp. 479-497. Abordo, entre otras, esa faceta "escolar» en «Las justas poéticas en el siglo XVI», Begoña López Bueno (ed.), El canon poético en el siglo XVI: un proceso en marcha. VIII Encuentro Internacional sobre Poesía del Siglo de Oro, [en prensa]. 
los alumnos para la composición poética, y no solo en latín. Sin duda, el pragmático afán laudatorio hacia destacadas personalidades o la exaltación de conceptos y figuras religiosos serían lo suficientemente fuertes como para pasar por alto la estricta ejercitación académica en aras de la pública adhesión a eventos colectivos. Lógicamente, para cronologías más tardías, la valoración intrínseca, y no solo para la homilética, de la elocuencia castellana haría que la paridad no necesitara de tales coartadas.

En el terreno de la métrica, como en otros, no puede descartarse la utilización directa de tratados amplios, no adaptados a un específico uso escolar, como por ejemplo el Arte de Rengifo ${ }^{12}$. Pero con esta salvedad, para la documentación anterior al siglo XVIII, resultan de interés los apuntes destinados a (o procedentes de) la enseñanza, probablemente de grado medio, por desgracia muy vulnerables al deterioro y la dispersión. Valgan dos ejemplos de contexto jesuítico, posiblemente datables en el último tercio del siglo XVII.

Uno de ellos aparece en el ms. 9/2535 de la Academia de la Historia, un volumen orientado hacia el aprendizaje teórico y práctico del latín, lengua casi constante en el manuscrito. Hacia el final, unas cuantas páginas recogen unas "Breves noticias de la Poesía Castellana» ${ }^{13}$. Estas se reducen a nociones métricas, y la escueta introducción previa, sin cuestionar el estudio de la poesía, refleja las reservas subyacentes:

No es mi intento ceñir dentro de tan cortos límites la dilatada esfera de la Poesía Castellana, sino solamente dar los primeros elementos de ella. Si bien es esta una arte que, suponiendo las noticias más precisas, mejor se alcanza con la práctica y con la

12. De hecho, la dedicatoria del libro revela ya ese uso, por parte del propio autor: "convenía no faltase también quien despertase nuevas venas de poetas que dignamente las celebrasen [las hazañas de la familia del dedicatario] y extendiesen por el mundo, que es uno de los principales fines a que se endereza este libro. Cuya teórica, aun en su nacimiento, ha comenzado a dar fruto, pues de ella salieron los varios epitafios, canciones fúnebres y hieroglíficos que en esta Universidad sacaron los vasallos de V. S. cuando el cuerpo de mi señora la Condesa fue traído de Valladolid y sepultado en el monasterio de Santa Úrsula.» (h. 5r).

13. Ms. 9/2535 RAH, pp. 650-664. La inclusión de un jeroglífico sobre San Francisco de Borja hace pensar en la celebración de su canonización, en 1671, y por tanto, en una fecha posterior para estos apuntes de métrica. Después de estos, cerrando el volumen, aparecen unos villancicos al mismo santo (la precisión del epígrafe está refrendada por su inclusión en Ambrosio de Fomperosa y Quintana, Días sagrados y geniales, celebrados en la canonización de S. Francisco de Borja. Por el Colegio Imperial de la Compañía de Jesús de Madrid. Y la Academia de los más célebres ingenios de España, Madrid, Francisco Nieto, 1672, f. 108r-108v y 110v$111 \mathrm{r}$ ) y varios poemas por la muerte de la reina madre, dońa Mariana de Austria (por tanto, 1696); no tienen por qué ser coetáneos de los apuntes, pero sí resultan orientativos. 
leyenda de Poetas, que cargando de preceptos. Entre estos debe ser el primero no abusar de esta Arte para cosas profanas, ni aprenderla en libros menos puros, por no beber ponzońa con el dorado cáliz de Babilonia. No faltan autores en quienes se pueda aprender la propiedad y elegancia sin arriesgar la conciencia. (p. 650)

Junto a valores de moralidad, propiedad y elegancia, tan breves líneas revelan el carácter propedéutico del conocimiento métrico, no autónomo, sino dirigido a la práctica inmediata, lo cual en parte explica que tampoco se presente como un saber histórico. El elenco métrico queda reducido al romance, décima, redondilla, quintilla y terceto menor, soneto, octava, canción real, lira y sexteto-lira (aquí llamado lira italiana), ovillejo o silva de consonantes (se refiere a ello como «unas relaciones que llaman versos de consonantes» ${ }^{14}$ ), jeroglífico y glosa. Y esto, con escasas excepciones, equivale a decir las combinaciones más extendidas a partir del siglo XVI, aunque también, con el tercetillo o el jeroglífico, destaca la relevancia relativa de formas solo generalizadas en contextos muy concretos, para inscripciones y otras formas de poesía circunstancial.

Ello gravita sobre los fragmentos que sirven de ejemplo. La anonimia, aunque predominante, no es sistemática. Quizás no sea ocioso recordar a Rengifo en su prólogo al lector, cuando precisa que ilustra sus explicaciones "con ejemplos a lo divino de buenos poetas. Los cuales no tanto pongo por la elegancia (aunque esta no falta), cuanto por la consonancia que en ellos se enseña» ${ }^{15}$; con ello viene a declarar cierta irrelevancia autorial, pese al expresado criterio selectivo, pero no una irrelevancia de contenido, pese al fin métrico y al carácter fragmentario de las citas. En el manuscrito que ahora trato, el criterio cualitativo ni siquiera queda sugerido, y la selección de textos - con sus implicaciones autoriales- se muestra mediatizada no solo por su función de ejemplo métrico, sino también, a veces, por la adecuación a contextos celebrativos.

Los apuntes contienen veintiuna citas, y solo cinco están atribuidas: una décima de Lope de Vega a San Isidro y una estrofa de canción burlesca al mismo santo de su heterónimo, Tomé de Burguillos ${ }^{16}$, unas redondillas de Pérez de Montalbán, un soneto de Lupercio Leonardo de Argensola -aquí

14. Ms. 9/2535 RAH, p. 660.

15. Juan Díaz Rengifo, op. cit., h. 2v.

16. Ambas proceden de sendas justas poéticas: Lope de Vega Carpio, Justa poética y alabanzas justas que hizo... Madrid al bienaventurado San Isidro en las fiestas de su beatificación, Madrid, Viuda de Alonso Martín, 1620, f. 57v; Lope de Vega Carpio, Relación de las fiestas que... Madrid hizo en la canonización de... San Isidro, Madrid, Viuda de Alonso Martín, 1622, f. $63 \mathrm{v}-64 \mathrm{r}$. 
manipulado ${ }^{17}$-, y una octava de Góngora - procedente del Polifermo, aunque no se indica, y con un contenido geográfico-mitológico que permite dudar de un criterio de selección meramente esteticista-; además, para una glosa anónima se aduce a Rengifo ${ }^{18}$. De los demás versos, solo he podido identificar una quintilla de Boscán, una redondilla recogida por Juan Rufo y Gracián, y una lira y una estrofa alirada de sendos autores prácticamente desconocidos para una justa zaragozana a Santa Teresa ${ }^{19}$; con todo, si ya el concepto de autoridad resulta endeble en estos apuntes, para los autores no identificados el valor de la mera selección parece bastante diluido. Por el contrario, me parece significativo que más de la tercera parte de las citas remita a referentes religiosos ${ }^{20}$, y que otras, con tópicos descriptivos o laudatorios comunes, puedan pertenecer a poemas similares; el hecho de que algunas procedan de justas poéticas evoca el posible mundo de referencia del elaborador de los apuntes, y quizás esté trasluciendo el perfil de poesía para el que se adiestraría a los escolares.

El segundo ejemplo, también posterior a 1671, muestra cómo, con objetivos similares, pudieron convivir matices distintos; se trata del ms. 9/2609, también de la Academia de la Historia, de entorno jesuita andaluz y abundante material poético, que recoge una «Breve noticia de la Poesía castellana para el uso de la clase» ${ }^{21}$. Como en el caso anterior, título tan

17. Es el poema «Dentro quiero vivir de mi fortuna». En el original, la sucesión de tópicos neoestoicos (aceptación de la propia fortuna, deseo de una vida ajena a la aspiración a la fama y no sometida a las opiniones del vulgo, conciencia de la proximidad entre cuna y sepultura) da en el último terceto un giro inesperado, de corte amoroso: "¿qué más aplauso quiero o más provecho / que de Filis mi fe ser admitida / y estar yo de la suya satisfecho?» (cito por Lope de Vega, Relación de las fiestas..., cit., f. 125v-126r, posible fuente utilizada, casi sin variantes, a diferencia de las versiones, cercanas entre sí, de las Flores de poetas ilustres de Pedro Espinosa y los Discursos, epistolas y epigramas de Artemidoro, de Andrés Rey de Artieda). En los apuntes, una variante revela clara intencionalidad: la sustitución del nombre de la amada por el de Cristo, dotando así a la renuncia de los valores mundanos de unos precisos contornos religiosos, más afines al contexto docente donde se recoge el soneto.

18. Las citas, en pp. 655, 659-660, 656, 657, 658 y 663-664, respectivamente.

19. Ibid., pp. 656 («El señor de mi sentido...»), 662 («Aunque pobre y en pelota...»; sin atribución) y 660 (la primera, de fray Martín de la Madre de Dios -con la lectura «Dios», en vez de «Él», en el primer verso-, la segunda de Martín Hernando Ezquerra, ambas en Luis Díez de Aux, Retrato de las fiestas que a la beatificación de la bienaventurada Virgen y Madre Santa Teresa de Jesús... hizo... Zaragoza, Zaragoza, Juan de la Naja y Cuartanet, 1615, p. 72).

20. Aparte de las ya referidas: unas coplas de romance «a los montes de Monserrate» (p. 654), una copla de seguidilla con referencia a Cristo (p. 653), un tercetillo dirigido a Santa Gertrudis (p. 657), una cuarteta de romance dirigida a San Antonio Abad (p. 662) y un jeroglífico a San Francisco de Borja (p. 662).

21. Se encuentra en los f. 103r-116r. El término a quo lo vuelve a establecer un poema a la canonización de San Francisco de Borja, en este caso unas endechas de Antonio de 
semejante remite únicamente a métrica. Las citas son más numerosas, en parte porque, a diferencia del otro manuscrito, se extienden también por los rudimentos de medida y rima; se puede aislar más de medio centenar, aunque muchas son de un solo verso, y algunas ilustran fenómenos lingüísticos no específicos de la poesía. La anonimia solo afecta a siete citas, casi todas encasillables en dos categorías bastante propicias, el terceto o tercetillo, a modo de epigrama breve, y villancicos y seguidillas de aparente difusión musical. Si bien en estas últimas composiciones y en varios fragmentos de autor identificado vuelven a dibujarse géneros o contenidos característicos de la fiesta religiosa, la impresión de conjunto no queda tan marcada por tal contexto como en el caso anterior.

Para el elenco de autores merece la pena distinguir entre los rudimentos generales y la relación de estrofas, pues los primeros están menos condicionados para la selección de ejemplos y, por tanto, pueden reflejar más directamente las preferencias. En esa parte inicial, el más destacado es, como se le llama en varias ocasiones, el "Príncipe de la Poesía Castellana», Garcilaso, sobre todo con ejemplos de sus églogas, pero también de sus elegías y epístola y de cuatro sonetos; le acompañan varios fragmentos de Quevedo, otros de un poema a Santa Teresa de Juan de Jáuregui y uno de la traducción de Fray Luis del Beatus ille; en un añadido al margen, también se aduce un verso de un soneto de Góngora. Aunque con parquedad, en el repertorio estrófico estos autores se mantienen, entre ellos Góngora, ya integrado en el texto, con «su nunca bastantemente celebrado Polifemo» ${ }^{22}$; sin embargo, el protagonismo de estos se diluye en un elenco más diversificado y actualizado: Bocángel, Ulloa, un tal Juan de Córdoba, González de Salas, «el famoso Poeta Juan de Mena» ${ }^{23}$-inevitable si se quiere ilustrar las coplas de arte mayor-, Antonio de Mendoza, Lope de Vega -sólo en una ocasión- y Antonio de Solís. Pese a la humildad de tales apuntes de métrica, el concepto de autoridad aflora, pues, en la notable proporción de versos atribuidos y la fuerte selección de la parte introductoria -relativamente afín a elencos posteriores-, aunque solamente lo hace de manera muy limitada en comentarios estimativos.

Las dificultades de localización de una documentación similar continuada y datable nos privan de un proceso de evolución que, hacia mediados del siglo XVIII, se muestra decantado hacia valores literarios y contextos docentes en apariencia muy diferentes. Los factores coadyuvantes pasan, entre otros, por el afianzamiento de la gramática espańola como objeto de estudio específico,

Solís (también en la relación de Fomperosa y Quintana citada, f. 152r-153v). Algunos textos fechados en el manuscrito remiten a fechas no muy lejanas, entre 1672 y 1682.

22. Ms. 9/2609 RAH, f.108r.

23. Ibid., f. 112r. 
la potenciación de planteamientos historicistas, o la formación y difusión de unos juicios de valor ligados a la noción de buen gusto y regidos no solo por criterios estilísticos individuales, sino también por la periodización literaria. Avanzado el siglo XVIII, y pese a las limitaciones, la literatura española se hace más visible en la documentación escolar, en parte por su mayor presencia en la formación y en los impresos a ella destinados, en parte por la creciente reglamentación de los centros educativos y por el interés propagandístico de algunos de ellos.

Precisamente una de las fuentes más ilustrativas del currículum escolar y la metodología docente la constituyen los «Exámenes públicos», «Ejercicios literarios», "de letras» $\mathrm{o}$ "de humanidad», de los que dan constancia numerosos folletos. Al menos en su proyección impresa, es un fenómeno algo tardío, pues repertorios ampliamente documentados como los de Carmen Simón Palmer para Madrid y, para las Escuelas Pías en Espańa, Vicente Faubell Zapata, nos sitúan, aún con cierta dispersión, en el segundo cuarto de siglo, y con especial intensidad a partir de los ańos sesenta, aunque es de suponer que existía firme tradición anterior ${ }^{24}$. En ellos se reflejan los actos públicos en los que, entre el examen y la ostentación celebrativa, los alumnos daban cuenta de las enseñanzas recibidas.

Dos ejemplos pueden ilustrar la utilidad y limitaciones de estos materiales. El primero, de nuevo en ámbito jesuita, es un impreso relativo a unas fiestas del Seminario de Nobles de Valencia, en $1745^{25}$. En él se recoge un acto que combina la justa literaria escolar, con amplia propuesta de composición en metros latinos y castellanos, y el examen de destrezas propias del currículum académico, como la traducción. De hecho, el certamen requirió un refuerzo o reorientación de enseñanzas: «Fuera de las ordinarias tareas de las Clases que son de todos tiempos, este ańo la de Mayores tuvo otras extraordinarias, a fin de que los alumnos de ella se habilitasen para coronarle de laureles de

24. María del Carmen Simón Palmer, «Notas bibliográficas sobre programas de exámenes públicos celebrados en Madrid de 1632 a 1844», Anales del Instituto de Estudios Madrileños, VIII (1972), pp. 501-517; del siglo XVII solo se testimonian «conclusiones» políticas, bíblicas o teológicas, y matemáticas y filosóficas, entre 1734 y 1760. Vicente Faubell Zapata (Acción educativa de los Escolapios en España (1733-1845), Madrid, Universidad Pontificia de Comillas-Fundación Santa María, 1987) incluye un catálogo cronológico, con solo dos muestras anteriores a 1727, en pp. 613-621; para el balance de la presencia de la Literatura española en estos ejercicios, véanse pp. 491-496.

25. Joaquín Castelví y la Figuera, Mercurio Sacro y Poético, en el cual se contienen algunas noticias tocantes a los progresos que en Virtud y Letras hace la Juventud Valenciana que cursa las Escuelas del Seminario de Nobles de San Ignacio. Acreditados en las solemnes fiestas y certamen literario del año Escolar 1745, Valencia, José Estevan Dolz, [¿1746?]. 
Apolo» ${ }^{26}$. El proceso de adiestramiento parte de una nómina de poetas y prosistas latinos (Fedro, Ovidio, Marcial, Virgilio, César y Cicerón), y pasa de la consideración y análisis de sus valores, explícitamente diferenciados, a la ejercitación personal ${ }^{27}$. Pero la poesía española queda de nuevo silenciada, pese a su presencia en el acto en dos vertientes: de un lado, con la composición de poemas; de otro, con la cita de poetas españoles - con una reducida nómina explícita de resabios barrocos- para la ilustración y comentario de la traducción de textos latinos. Tal metodología viene explicada así:

Vueltos los veinte Certantes al Teatro, se formaron en él, como en la primera salida, y fueron por su orden vertiendo en espańol los autores latinos, explicando sus erudiciones y confirmando sus figuras y tropos con textos de los más clásicos poetas españoles, especialmente de Don Luis de Góngora y Argote, de Don Antonio de Solís y Rivadeneyra y de la poetisa americana Sor Juana Inés de la Cruz, que en lo profundo y armonioso, en lo natural y discreto, en lo ingenioso y fecundo, hacen que nuestra Nación no tenga cosa que envidiar a los poetas latinos. (pp. 63-64)

El segundo ejemplo, también valenciano, procede del otro pilar en la enseñanza no universitaria desde finales del siglo XVII, y muy especialmente en el XVIII, las Escuelas Pías. Se trata de una Academia de Bellas Letras celebrada en 1788, también ella con una ambivalente actitud hacia la poesía espańola ${ }^{28}$. Por una parte, la subordinación de esta al estudio de la literatura clásica sigue siendo clara; además, el discurso latino pronunciado, en defensa de la gloria de los españoles en materia literaria, ni siquiera aborda la poesía castellana ${ }^{29}$. Por el contrario, esta sí está presente en los ejercicios de composición poética, que, con evidente interés clasicista, se emplean en pareados, liras, octavas y sáficos y anacreónticos españoles; es de suponer que también afloraría en las Lecciones de Poética que los alumnos debían recitar, pues su temario incluye un punto sobre el «origen de la poesía vulgar»y otros sobre géneros como la égloga o la poesía lírica, que en Poéticas escolares del momento propician ocasionalmente la mención de poetas españoles.

\footnotetext{
26. Ibid., p. 39.

27. Ibid., pp. 39-42.

28. Academia de Bellas Letras que ofrecen a su munifico patrón el Excelentísimo Señor D. Francisco Fabián y Fuero, Arzobispo de Valencia, [...] los discipulos de las Escuelas Pias bajo la dirección del P. Jerónimo de S. Blas Maestro de Retórica, Valencia, Benito Monfort, [s. a., 1788].

29. Ibid., pp. 22-44. Lógicamente, se entiende la «materia literaria» en el sentido amplio dieciochesco. Hay, en cambio, referencia al florecimiento medieval de la poesía provenzal en el reino de Aragón (pp. 37-38).
} 
Además, con un canon típicamente neoclásico, se indica que "con el fin de ejercitar más en ellos [en los alumnos] el gusto de la Poesía, y de presentarles más fácil su estudio, se les ha dado noticia de los mejores poetas españoles como Garcilaso, el Maestro León, los Argensolas y otros. Han aprendido y dirán algunas canciones selectas de ellos, y algunas de las Fábulas Españolas de Samaniego y de las Literarias de Iriarte» ${ }^{30}$. Por otra parte, para el ejercicio de griego los alumnos debían recitar odas de Anacreonte y la correspondiente versión de Esteban Manuel de Villegas ${ }^{31}$.

Con todo, estas someras referencias a autores españoles resultan valiosas por su rareza en medio de una documentación que, como mucho, consagra unos cuantos modelos retóricos en prosa (Fray Luis de Granada, Fray Luis de León, el Padre Mariana, Diego Hurtado de Mendoza, Antonio de Solís), y también unos pocos poetas. Los datos de Faubell Zapata, a partir de amplia documentación escolapia, indican como poetas españoles objeto de consideración en los ejercicios públicos del siglo XVIII Fray Luis de León, sobre todo, Garcilaso de la Vega, y en menor medida Esteban Manuel de Villegas, los hermanos Argensola y Ercilla -utilizado este a veces como ilustración para conocimientos de Geografía-, aparte del portugués Camoens y los dieciochescos Samaniego e Iriarte ${ }^{32}$.

En realidad, estas prácticas confirman lo que algunos manuales escolares de la segunda mitad del siglo XVIII, con distinto grado de atención hacia la producción vernácula, empiezan a reflejar. La Retórica se muestra menos receptiva con los poetas, quizás por reticencias hacia las peculiaridades de la construcción poética ${ }^{33}$. A ese respecto, Joaquín Traggia, en su Retórica filosófica, señala que «los poetas podrán ayudar a esto [a la educación en el ritmo de la prosa], si el Orador sabe hacer diferencia entre el número oratorio y poético; mas si su oído es poco fino, recibirá en esta parte más daño que provecho de la Poesía» ${ }^{34}$, aunque en otro momento reconoce que «los poetas, particularmente los antiguos, y sobre todos Homero y Virgilio, fecundarán tu entendimiento de imágenes, de razones y de tanta abundancia de noticias y cosas, que, ayudado de una buena lógica, podrás sacar más

30. Academia de Bellas Letras, cit., p. 16.

31. Ibid., p. 17.

32. Vicente Faubell Zapata, op. cit., pp. 492-495.

33. Véase, no obstante, Françoise Étienvre, «Antigua y nueva retórica en tiempos de Carlos III", Actas del Congreso Internacional sobre "Carlos III y la Ilustración». Tomo III: Educación y Pensamiento, Madrid, Ministerio de Cultura, 1989, pp. 153-173.

34. Joaquín Traggia de Santo Domingo, Retórica filosófica, o principios de la verdadera elocuencia, [...] a uso de los discípulos de las Escuelas Pías, Viuda de Francisco Moreno, 1793, pp. 28-29. 
materiales de su lección, que de todos los lugares comunes» ${ }^{35}$; con todo, solo en el apartado que reserva a la Poética, y dejando ahora aparte el teatro, menciona a poetas modernos como Petrarca, Camóes, Tasso, etc., y entre los españoles, los hermanos Argensola, Fray Luis, Villegas y Moratín ${ }^{36}$.

En esa línea, varias retóricas escolares, como la publicada a nombre de Manuel Merino o la de Juan Barberá y Sánchez, prescindirán por completo o solo registrarán alguna referencia aislada de autores espańoles, y aun eso de prosistas $^{37}$. La de Calixto Hornero de la Resurrección, que desde el propio título anuncia «ejemplos latinos de Cicerón y castellanos de fray Luis de Granada», a la hora de las recomendaciones hará una nómina más amplia, pero también solo de prosistas, todos ellos con obras históricas, eruditas o religiosas, salvo Cervantes con El Quijote ${ }^{38}$.

La Poética, por su parte, va integrando a los poetas españoles, normalmente en conjunción con sus homólogos clásicos. Ya en 1757 el Compendio del arte poética de Antonio Burriel introduce numerosas menciones, positivas y negativas, de poetas españoles ${ }^{39}$, e incluso remite, para más detalles, a la obra de Luis José Velázquez, Orígenes de la poesía castellana, publicada solo tres ańos antes, en la que delega, entre otras cosas, para la periodización literaria, que no estima propia de su manual ${ }^{40}$. Sus precisiones sobre la licitud moral de algunos contenidos amorosos, que permiten poner a salvo el modelo de

35. Ibid., p. 115.

36. Los poetas españoles son citados a propósito de la poesía lírica, por sus estrofas más extensas que las latinas -en este caso, junto con Petrarca-, o como ejemplo de oda anacreóntica (pp. 201 y 203).

37. Manuel Merino, Tratado de Retórica para el uso de las escuelas, Madrid, Juan Antonio Lozano, 1775; Francisco Aguilar Piñal considera «más que probable su atribución al P. Andrés [Merino]» (Bibliografía de autores españoles del siglo XVIII, vol. V, Madrid, CSIC, 1989, no 4775). Juan Barberá y Sánchez, Reglas ordinarias de retórica, ilustradas con ejemplos de oradores y poetas del siglo de oro, para uso de las escuelas, Valencia, Francisco Burguete, 1781.

38. Calixto Hornero de la Resurrección del Señor, Elementos de Retórica con ejemplos latinos de Cicerón y castellanos de fray Luis de Granada para uso de las escuelas, Valencia, Benito Monfort, 1777, pp. 197-198.

39. Antonio Burriel, Compendio del arte poética, sacado de los autores más clásicos, para el uso e instrucción de los caballeros seminaristas del Real Seminario de Nobles de Madrid, Madrid, [s. i.], 1757; también en Colección de varios tratados curiosos, proprios y muy útiles para la instrucción de la noble juventud española, que publica el Real Seminario de Nobles de Madrid, para el uso de los caballeros seminaristas [...] Tomo IV. Que contiene los compendios de la Historia Mitológica y del Arte Poética, Madrid, José Rico, 1757, pp. 187-397. Para las citas utilizo la edición exenta.

40. Op. cit., p. 11. Vuelve a remitir a él al hablar de las cualidades de dulzura y belleza, y de Garcilaso y Fray Luis como sendos modelos: «La noticia de otros autores nuestros puede verse en Velázquez [...] y el camino más breve para adelantar será la lectura de los más escogidos» (p. 53). 
Garcilaso, o la identificación de este y de Fray Luis como las dos cimas de la poesía española, "comparables a los antiguos», son dos ideas que pueden verse en los fragmentos recogidos en el Apéndice (Texto no 2). También se podrían mencionar las críticas a ejemplos de poesía conceptuosa, como la famosa copla "Ven, muerte, tan escondida» ${ }^{41}$, o a un soneto de Góngora ${ }^{42}$, o a la utilización de redondillas para un poema épico por parte del Conde de la Roca ${ }^{43}$, etc.

Andrés Merino, en su Breve tratado de poesía latina y castellana (1781), dirime cuestiones como la inexistencia en castellano de un auténtico poema épico o la identificación de modelos líricos (de nuevo, Garcilaso, Fray Luis, los Argensola, pero también Herrera ${ }^{44}$ ), individualizados en sus valores específicos y, al mismo tiempo, aquí sí asociados a la periodización literaria y sus prejuicios anejos (véase Apéndice, Texto no 5).

Juan Cayetano Losada, en sus Elementos de poética (1799), no desatenderá la presentación de los poetas dentro de coordenadas históricas, con un claro ensanchamiento de la nómina, y juicios tanto positivos como negativos, a veces incluso contrapesados en un mismo autor, como cuando condena la «hinchazón y vana pompa, vicio que ha degradado mucho de su mérito a un Góngora y Lope de Vega en muchas de sus obras» ${ }^{45}$, o cuando afirma que «en nuestra lengua Castellana, aunque los sabios no reconocen por completo y perfecto ningún poema épico, por haberse dejado arrastrar nuestros poetas de su ingenio con demasiada libertad, sin embargo, hay muchos rasgos dignos de la majestad de la epopeya en Ercilla, aunque se le nota más de historiador que de poeta, y en Villaviciosa, sin embargo de no haber elegido una materia propia de la Epopeya» ${ }^{46}$.

También en el terreno de la Gramática, algún manual refleja la recomendación de lectura de los buenos poetas nacionales. Así, de la gramática latina publicada a nombre de Agustín de San Juan Bautista en

41. Ibid., pp. 65-66.

42. Se trata del soneto dedicado a Luis de Babia («Este que Babia al mundo hoy ha ofrecido...»), y el autor hace referencia, también, a la crítica del mismo por parte de Luzán. Ibid., pp. 111-113.

43. Ibid., pp. 121-122.

44. Sobre la variable estimación de Herrera en el siglo XVIII puede verse Emilio Palacios Fernández, «Los poetas de nuestro Siglo de Oro vistos desde el XVIII», II Simposio sobre el Padre Feijoo y su siglo, vol. II, Oviedo, Centro de Estudios del Siglo XVIII, 1983, particularmente pp. 532-533.

45. Juan Cayetano Losada, Elementos de Poética extractados de los mejores AA. [autores] e ilustrados con ejemplos latinos y castellanos, y un apéndice sobre las especies de versos más comunes en nuestra lengua, Madrid, Viuda e hijo de Marín, 1799, p. 39.

46. Ibid., p. 137. Véase, además, el Apéndice, Texto no 6. 
1769, se pueden destacar las precisiones metodológicas sobre el uso de poetas españoles en la enseñanza del latín, con el emparejamiento según géneros literarios y la utilización tanto de textos originales como traducciones ${ }^{47}$.

Pero, sin duda, sobresale el Arte del romance castellano, del escolapio Benito Feliú de San Pedro, asimismo publicado en 1769, cuya condición de gramática castellana no impide un mismo planteamiento de conjunción de autores latinos y espańoles ${ }^{48}$. A los objetivos y contenidos propios de una gramática, Feliú añade todo un primer tomo sobre la evolución histórica del castellano y de sus manifestaciones literarias. Insertas en tal diseńo histórico, sus nóminas de autores son muy detalladas, incluso para la Edad Media. El autor sigue básicamente el modelo explicativo habitual de oscilación entre esplendor y decadencia; sin embargo, introduce juicios matizados con respecto a esta última, entre otras cosas porque inicia este período en el reinado de Felipe III y no en el de su hijo, con lo que la valoración global no resulta enteramente negativa, y porque atribuye la decadencia, más que a autores como Góngora o Paravicino, a imitadores suyos de inferior ingenio y erudición, al tiempo que con Lope o Quevedo, entrevera elogios y críticas o reservas (véase Apéndice, Texto no 3). El primer tomo se cierra, además, con más de veinte páginas dedicadas a un "Catálogo de los Autores de mayor nota en todas las edades de nuestra lengua para uso de los que estudian", precedido de las siguientes instrucciones:

Para que los principiantes y poco instruidos tengan regla fija de los autores que deben leer como Padres de la lengua, pondré un catálogo

47. Gramática de la Lengua Latina... nuevamente dispuesta e ilustrada a uso de las Escuelas, Valencia, Benito Monfort, 1769, en «Del método y uso de esta gramática. Al letor» (véase Apéndice, Texto no 4). En realidad no se trata de una reedición, sino de una reelaboración, de la anterior gramática latina del P. Agustín Paúl; sobre la atribución a Benito Feliú de tal reelaboración y del prólogo, véase Vicente Faubell Zapata, op. cit., pp. 459-463.

48. Benito de San Pedro, Arte del romance castellano dispuesta según sus principios generales y el uso de los mejores autores, Valencia, Benito Monfort, 1769 (véase Apéndice, Texto no 3); para su biografía y el contenido de la obra puede verse Eulalia Hernández Sánchez y M.a Isabel López Martínez, "Las ideas lingüísticas en el Arte del Romance Castellano de Benito de San Pedro", Mas de las Matas, 16 (1997), pp. 199-357. Tres décadas después, Juan Cayetano Losada vuelve a utilizar el espacio prologal para justificar esta metodología; la antología de Autores selectos de pura latinidad le permite omitir las citas de estos, dejando espacio para las de autores castellanos: «Pues con estos ejemplos castellanos lograrás, como ya tengo experimentado, comprender los preceptos con más facilidad aún que con los latinos y adquirir algún conocimiento de las muchas bellezas que nos han dejado nuestros poetas, pues es cosa vergonzosa buscar las gracias de las lenguas extrańas y descuidarnos de las de la nuestra, pues aunque los latinos sean los modelos por donde debe formarse todo poeta, como lo fueron de los romanos los griegos [...], sería una intolerable negligencia ignorar los nuestros» (op. cit., h. 3). 
de los autores príncipes de todas sus épocas. Son textos todos los que se ponen del siglo decimosexto, aunque unos escribieron con mayor estilo que otros. En los de las otras edades hay qué imitar y qué despreciar. Se indican las materias de que tratan para que desde luego se tome la letura de aquel autor en cuyo asunto habemos de hablar o escribir. (p. 101)

Del efecto de la nómina es ilustrativo el reproche que le hace un detractor de la obra: haber copiado directamente de la lista de autores que precede al Diccionario de Autoridades de la Real Academia ${ }^{49}$. Por lo demás, tal es el convencimiento de Feliú en la virtud de los ejemplos autorizados, que incluso en la parte estrictamente gramatical del manual, aunque sea para ilustrar las formas del artículo, el uso del presente histórico o el de las preposiciones, por poner solo algunos ejemplos, menudean las citas de grandes autores: especialmente Fray Luis y Garcilaso, aunque también aparecen, aparte de prosistas, Ercilla y la traducción de la Eneida realizada por Hernández de Velasco, alguna vez Bartolomé Leonardo de Argensola, Lope de Vega y unos versos de Diego Hurtado de Mendoza, e incluso Juan de Mena. Una nómina, pues, relativamente selectiva y con claras preferencias en comparación con los amplios listados de la sección histórica.

Frente a lo que se señalaba para los apuntes de métrica del siglo XVII mencionados, este apresurado recorrido por algunas retóricas, poéticas y gramáticas escolares de la segunda mitad del siglo XVIII permite ilustrar las diferencias de contexto ideológico e intenciones, que pueden sintetizarse en los siguientes puntos:

1) La mención de los poetas españoles sale del reducido espacio de la métrica hacia zonas más amplias de la poética, sobre todo en torno a la definición e ilustración de los distintos géneros; de hecho, se suele desatender

49. «Don Juan. ¿Y de dónde copió aquella runfla o cáfila de autores que está desde la pág. 102 hasta la 123 del Origen y Épocas del Romance [...]?. Don Antonio. Del primer Tomo del Diccionario de la Lengua Castellana, pero no todos, sin hacerse cargo de que la docta Academia Española pone aquel Catálogo de Autores como fuentes de donde se han sacado las voces castellanas, pero no como Patriarcas del Romance» (Antonio Gobeyos [pseudónimo de Benito Martínez Gómez-Gayoso], Conversaciones críticas sobre el libro intitulado Arte del Romance castellano, publicado por... Benito de San Pedro, Madrid, Antonio de Sancha, 1780, pp. 102-103); más adelante la denomina «una ensalada italiana de autores buenos y malos, la mayor parte de ellos inútil para el fin que pretende el autor de que sean dechados del lenguaje puro castellano en sus respectivos tiempos» (p. 211). Otros muchos reproches atañen a la cita de autores que realiza el escolapio, como la inconveniencia de recurrir, para ilustración de la gramática, a poetas, en vez de a prosistas (pp. 192-193), o la supuesta preterición de Quevedo (pp. 218-221). Pueden verse referencias más sistemáticas al contenido polémico de la obra en Eulalia Hernández Sánchez y M. ${ }^{a}$ Isabel López Martínez, art. cit. 
el elenco de formas métricas, solo presente, entre los manuales citados, en el de Juan Cayetano Losada ${ }^{50}$. También la retórica da alguna cabida a estos poetas, pero suelen ser preferidos los prosistas.

2) La frecuente articulación en torno a géneros poéticos -entre ellos, el dramático, aquí no contemplado- sigue posiciones clasicistas que abordan la poesía castellana en función de la greco-latina. Se consagran, pues, las consideraciones en torno a la épica, la égloga y la lírica, en algunos casos con tratamiento aparte de la elegía y la sátira ${ }^{51}$. Ello reduce en buena medida el espectro poético español prestigiado, preferentemente identificado con la gama estrófica de la poesía italianizante, aunque consiguen recuperarse algunos géneros octosilábicos, como las letrillas de Góngora y Quevedo que, por ejemplo, en Juan Cayetano Losada aparecen asociadas a la sátira ${ }^{52}$.

3) En algunos casos resulta característica la reflexión sobre metodología docente. Entre otras cuestiones, se justifica la conveniencia de aplicar los conocimientos de retórica, poética y gramática al español, tanto para facilitar y afianzar la asimilación de las nociones propias de la lengua y literatura latinas, como para la adquisición de habilidades semejantes en la lengua propia. En este terreno destaca la justificación del estudio comparado de

50. Op. cit., pp. 157-183. Cabe ańadir, por ejemplo, el desordenado, y en gran parte deudor de las Tablas poéticas de Cascales, "Compendio del arte métrica castellana» que Juan Antonio González de Valdés incluye en su Gramática de la lengua latina y castellana, Cuaderno III, Madrid, Imprenta Real, 1791, pp. 111-117; básicamente, ilustra el verso de arte mayor, la octava, los tercetos, los versos octosílabos y otros más breves, la canción y el soneto; al final, sin definición, se nombran, mezclados, formas métricas y géneros, «cuyos nombres y distinciones y estructura se deben aprender imitando a nuestros poetas del siglo de oro», a lo que sigue una nómina tan heteróclita que parece extraida de un muestrario de ejemplos: «los Argensolas, los Villegas, Fray Luis de León, Arias Montano, Rebolledo, Manrique, Garcilaso, Calderón, Solís, Morales, Morillo, Lope de Vega, Pereira, Torre, Martín, Figueroa, Tejada, Velasco, Mesa, Jáuregui, Ezquerra, Polo, Espinosa, Artieda, Burguillos, y otros infinitos espańoles dignos del laurel inmortal de Apolo en todos los géneros de poesía» (p. 117).

51. Así, en el Compendio de Burriel, se agrupan égloga, elegía y sátira, adscribiéndolas -como explicita luego- a la poesía heroica («El Soneto pertenece a la poesía lírica, como las tres especies del capítulo antecedente a la heroica», p. 210). Andrés Merino, en su Breve tratado de poesía, fragmenta aún más: el capítulo III trata «de la Elegía, Epigrama, Sátira, Poema Lírico, Himno, Parodia y verso intercalar» y el IV, «de las Éclogas, Silvas, Diras, Epitalamio, Genetlíaco, Epicedio, Epinicio, Eucarístico, Propémptico, Sotérico, Protréptico y Parenético». Losada, por su parte, se esfuerza por articular esa variedad y graduarla según la complejidad del género de cara a los alumnos, de modo que, a «Algunos poemas menores» (donde incluye, entre otros, elegía, sátira, apólogo, epigrama y égloga), siguen la poesía dramática, la epopeya y la poesía lírica (esta última con las subdivisiones de himno, epitalamio, genetlíaco, etc.). En cambio, la epístola no recibe un tratamiento específico en ninguno de estos manuales.

52. «En la sátira castellana tenemos en Don Luis de Góngora algunas letrillas muy delicadas, y también en Don Francisco de Quevedo cosas muy finas», op. cit., p. 59. 
autores clásicos y españoles, sin que, desde luego, eso excluya la existencia de gramáticas, retóricas y poéticas en lengua vernácula ceñidas en doctrina y ejemplos al latín. A este respecto, hay que recordar que, fruto de esa conciencia metodológica y también de la creciente preocupación del Estado por el diseño de una política educativa, en 1768 un decreto real obliga al uso del español en la enseñanza del latín. Entre lo sintomático de un pensamiento educativo que se acaba consolidando en forma de imposición legal y la necesidad de adecuar los manuales a la misma, varios de los aducidos son unos años anteriores o, quizás no por azar, inmediatamente posteriores.

4) Las citas están guiadas por presupuestos de valor y ejemplaridad, con una nómina de autores reiterada de unos textos a otros. Normalmente no se trata de una ejemplaridad implícita, sino de juicios de valor expresos. No se siente ningún pudor, pues, en encomendar al adoctrinamiento escolar las consignas sobre el canon de autores ya sancionadas en otros contextos. Por otra parte, aunque no sea una apreciación frecuentemente explicitada o incluso asumida, algún texto parece desaconsejar una generalizada aplicación a la práctica poética, por lo que se debe conceder que, implícitamente, los objetivos docentes pudieron contemplar la educación del buen gusto también en la lectura o consumo ${ }^{53}$.

5) Los modelos están con frecuencia vinculados a una periodización literaria, concebida según una dinámica de épocas de esplendor y de decadencia, que a veces se aplica de manera automática a los autores, dando lugar a juicios positivos o negativos, aunque hay casos como el de Losada o Feliú, con justificaciones más detalladas y matizadas.

6) Por lo que respecta a la nómina concreta, no hay grandes sorpresas: Garcilaso, Fray Luis, los hermanos Argensola y Esteban Manuel de Villegas

53. Puede verse en el Apéndice, Texto no 4, el comentario acerca de mandar a los alumnos componer algunos poemas, "pero con pa[r]simonia, según las muestras de ingenio que ofrezcan los discípulos» (recuérdese la probable autoría de Benito Feliú, según lo dicho en la nota $\mathrm{n}^{\mathrm{o}}$ 47). Al menos en la edición de 1818 del Breve tratado de Andrés Merino, es significativa la precisión cuando se habla de los autores que «deben proponerse por modelo los que, con el talento necesario, quieran dedicarse al embeleso de la poesía española" (cursivas mías), e incluso más adelante se recuerda los "versos fríos, lánguidos, desaliñados y tan despreciables» que han escrito quienes no estaban dotados para ello (véase Apéndice, Texto no 5). Algunas declaraciones, aun manteniendo entre sus expectativas la adquisición de un óptimo estilo oral y escrito, insisten en la fase preliminar de formación del «buen gusto» a través de la lectura. Valga de ejemplo Losada: «[Los Elementos de Poética] salen ahora por primera vez a la luz pública, después de haber sido experimentados útiles para infundir el buen gusto en este bello ramo de las Letras Humanas» (h. 2r); o más adelante, cuando atribuye a los ejemplos castellanos «comprender los preceptos con más facilidad aún que con los latinos y adquirir algún conocimiento de las muchas bellezas que nos han dejado nuestros poetas» (h. 3v). 
son casi constantes, aunque a veces se amplía tan reducido elenco ${ }^{54}$. Garcilaso oscila entre la máxima consideración y un silencio quizás debido a motivos de muy diversa índole, desde la preferencia de asuntos morales y religiosos hasta el seguimiento estricto de fuentes clásicas y francesas ${ }^{55}$; en alguna ocasión también resulta implícitamente reducido a los géneros neoclásicos, en especial la égloga, para la que otros autores españoles prestigiados no ofrecían ejemplos ${ }^{56}$. Por otra parte, destaca un fenómeno que, pese a no ser en la época de exclusivo contexto escolar, tiene especial significado en la metodología docente: el reconocimiento hacia las traducciones poéticas -y por consiguiente, hacia la faceta de traductor de algunos autores-, tantas veces excluidas del canon actual ${ }^{57}$.

54. Puede confrontarse con las referencias que, a partir de otras fuentes coetáneas, entresaca Emilio Palacios Fernández, art. cit., pp. 517-543.

55. Pese a su rotundidad, tienen cierto aire de justificación ante posibles reticencias o prejuicios estas palabras de Burriel: «¿quién será tan remirado y tan rígido, que en el Príncipe de nuestra Lírica, por ejemplo, condene las blandas quejas de Salicio y de Nemoroso, o la larga historia que refiere Albanio de un amor sano y lleno de pureza, o la diversión de Tirreno y de Alcino al recoger su ganado?» (véase Apéndice, Texto no 2). En el otro extremo, sorprende que Joaquín Traggia, en su Retórica filosófica, al referirse a las estancias de canción, remita a Petrarca, los Argensola, fray Luis de León «y otros muchos», sin mencionar a Garcilaso (p. 201); tampoco lo hace con otro género característico, la égloga, donde solo cita los modelos de Teócrito y Virgilio (p. 205), ni con la elegía (p. 206).

56. Aunque el Compendio del arte poética de Burriel remite de pasada a Garcilaso, entre otros pocos autores más, a propósito del soneto y de la elegía (pp. 212 y 199), las citas más recurrentes proceden de sus églogas. Benito Feliú, en la sección gramatical de su Arte, aun no olvidando algún soneto y las elegías, insiste también en las églogas para las citas y, de hecho, se decanta por ellas en el prólogo: «Ejercítese esta [la memoria] en retener los mejores pasajes de los Patriarcas de la lengua, como las Arengas de Mariana, las Églogas de Garcilaso, un Canto de Ercilla, los Salmos del Maestro León» (p. XXIII).

57. Sobresale fray Luis de León, tanto por sus versiones clásicas como por las bíblicas (así, en el Compendio de Burriel y en el Arte de Benito Feliú); asimismo, es bastante apreciada la traducción de la Eneida de Gregorio Hernández de Velasco (de nuevo, por Burriel, y Feliú en su Arte y en el prólogo de la Gramática latina a nombre de Agustín de San Juan Bautista; y también por Losada); tras menciones genéricas al cultivo de la anacreóntica en Villegas quizás haya que ver igualmente su faceta de traductor, tal como evidencia la mencionada Academia de Bellas Letras de 1788. Burriel cita alguna que otra vez la Epistola de Dido a Eneas publicada en 1708 bajo el nombre de José Zenún (pseudónimo del jesuita José Núnez). Feliú, en su Arte del Romance Castellano, a Simón Abril, por su traducción de Terencio, a Gonzalo Pérez por la de Homero, y la "traslación antigua castellana de las Fábulas de Esopo» (véase, Texto no 3; por el paralelismo sintáctico, parece que también está pensando en un Asno de Oro traducido), aparte de Diego Gracián, mencionado entre la abundante nómina de su discurso «De la excelencia de la lengua espańola y necesidad de su estudio. Oración que se dijo en la Academia de Bellas Letras que celebró el Colegio Andresiano, año 1767, en las Escuelas Pías [...]», incluido en el manual (véanse especialmente, pp. 221-225); en el prólogo de la 
En tales condiciones, aunque algunos tardaron más de dos siglos y lo hicieron de la mano de sus propios modelos, los poetas españoles empezaron a entrar en clase...

\section{ApÉNDICE}

1) Constituciones del Real Seminario de Nobles de Madrid, [s. 1., s. i., s. a. (pero 1755, citado en p. 238)].

Todos los que se hallan en clases superiores harán del mismo modo alguna traducción de autores del mejor estilo, ya sean latinos, ya españoles, y las harán en todas las lenguas que saben o estudian. [pp. 185-186]

Retórica y Poesía

[...] Por lo que mira a los poetas, se explican con frecuencia Terencio, Virgilio, Horacio, sin olvidar otros antiguos, como Plauto, Claudiano, Lucano, Juvenal y Persio, ni algunos otros modernos, como Vanière, Rapin, el Antilucrecio y otros.

Se les ejercita en temas y argumentos proporcionados a sus especies, como son un período, o más, una descripción, una narración, un exordio, una chria, una breve amplificación sobre determinado asunto, por tales y tales lugares oratorios, por tales y tales figuras, la imitación de un lugar escogido de algún autor, una alabanza o vituperio, etc. Siempre sobre asunto proporcionado, y según sus talentos y progresos, se les proponen temas más extensos.

Del mismo modo se ejercitan en la Poesía latina y castellana, según que para una y otra descubren habilidad y inclinación. Se empieza primeramente haciéndoles unir versos desleídos, hasta que sepan hacerlos enteramente, y luego se ejercitan en componer descripciones, narraciones, epigramas y elegías.

Estas composiciones, tanto retóricas como poéticas, las leen en el aula, para que se habitúen a dar a cada cosa el sentido y pronunciación conveniente. [pp. 210-211]

2) Antonio Burriel, Compendio del arte poética, sacado de los autores más clásicos, para el uso e instrucción de los caballeros seminaristas del Real Seminario de Nobles de Madrid, Madrid, [s. i.], 1757.

En la Lírica y Elegíaca tampoco habría en qué detenernos, si hubieran conservado su primera institución. Y suponiendo que son utilísimas cuando se emplean en elogio de la virtud y de lo justo, solamente puede dificultarse que

Gramática Latina cita, asimismo, el Arte poética traducida por Vicente Espinel. 
lo sean cuando se emplean en cantar amores profanos. Pero debemos distinguir entre honestas inclinaciones, según dejamos dicho, y apetitos desreglados. [...] En efecto, ¿quién será tan remirado y tan rígido, que en el Príncipe de nuestra Lírica, por ejemplo, condene las blandas quejas de Salicio y de Nemoroso, o la larga historia que refiere Albanio de un amor sano y lleno de pureza, o la diversión de Tireno y de Alcino al recoger su ganado? [pp. 36-37]

En Espańa logramos dos excelentes poetas, y comparables a los antiguos, cuyo carácter, según yo juzgo, es cada una de las dos calidades principales que hemos tratado en este capítulo, no porque la belleza y dulzura no se hallen en ambos en sumo grado, sino porque cada uno, o por genio, o por alguna otra razón, se dejó llevar más el uno de la dulzura, y el otro de la belleza. Estos son los citados Garcilaso y Luis de León. Garcilaso, por donde quiera que va, lleva consigo la voluntad de sus lectores, y Luis de León llena los entendimientos con su belleza, asintiendo como por fuerza a lo justo, vivo y proprio de sus palabras y pensamientos. [...] Solís tiene también muchos golpes de muy singular belleza; y para ejemplo bastará su traducción de aquellas palabras de Horacio: Si fractus illabatur Orbis, impavidum ferient ruinae, las cuales traduce así:

Caiga el orbe hecho pedazos,

que quien vive en su inocencia

ceder puede a la ruina,

pero no puede temerla.

[pp. 52-53]

3) Benito [Feliú] de San Pedro, Arte del romance castellano dispuesta según sus principios generales y el uso de los mejores autores, Valencia, Benito Monfort, 1769.

Vicia mucho el habla el hacer esta letura a los principios indiferentemente sobre cualquier escritor. Los modelos y patriarcas del romance son, por consentimiento de todos los hombres doctos de la Nación, D. Diego de Mendoza, Garcilaso de la Vega, Juan Bos[c]án, el Maestro Fr. Luis de Granada, el Maestro Fr. Luis de León, el incomparable teólogo Benito Arias Montano, D. Fernando de Herrera, D. Alonso de Ercilla, Pedro Rúa, D. Esteban Manuel de Villegas, Gonzalo y Antonio Pérez, los hermanos Argensolas, Don Diego de Saavedra, Miguel de Cervantes. [p. XV]

Por la misma razón será muy oportuno hermanar las materias y autores latinos en que se ejercitan los de las aulas de Gramática, Humanidad y Retórica con la lección de los autores espańoles en que se han de ejercitar para el buen romance; y con esto no solo se adelantará mucho más en ambas lenguas, si que también se aficionarán los niños y tomarán el gusto de los diferentes asuntos, como de la Historia, de la Poesía, del Apólogo, de las Cartas, porque entenderán fácilmente el artificio de una pieza en la lengua propria, pero con dificultad en la extranjera, por más que los maestros se esfuercen en la explicación. En consecuencia, se 
pondrá en manos de los estudiantes al mismo tiempo a Fedro con el Asno de oro de Apuleyo o la traslación antigua castellana de las Fábulas de Esopo; Cornelio Nepote o a Salustio con las Guerras de Granada de Mendoza; a las obras de Cicerón con las de Luis de Granada; las de Ovidio con Los Pastores de Belén de Lope de Vega y la Araucana de Ercilla; a Virgilio con Garcilaso; a Horacio con el Maestro León y los Argensolas, y así en los demás; singularmente en los estudios de Humanidad y Retórica es más importante unir las piezas espańolas y latinas de un mismo género para la sólida instrucción de los jóvenes. [pp. XVII-XVIII]

Capítulo VI. Época III de la lengua Española. Su edad varonil, y de su perfección. Por todo el Siglo XVI, su Siglo de Oro.

[...] Los príncipes, pues, y fundadores de la perfección de nuestra lengua se instruyeron a fondo en los estudios de humanidad y en el conocimiento de las lenguas griega, latina e italiana, y desbastando al romance y limándolo, le dieron como por grados la maravillosa pureza, elegancia y extensión que admiramos en sus escritos. Tales son, a más de Antonio de Lebrija, Garcilaso de la Vega, Gonzalo Pérez, Don Diego de Mendoza, Fr. Luis de Granada, el Maestro León, Jerónimo Zurita, Francisco Sánchez de las Brozas, Benito Arias Montano, Ambrosio de Morales, que entre los otros esclarecidos escritores de este siglo podemos respetar como Padres de la Elocuencia Castellana. Garcilaso, Príncipe de nuestra Poesía, con la fuerza de su ingenio y trato con los extranjeros, manejó la lengua con tal dulzura, gravedad, pureza y elegancia, que, compitiendo con Virgilio, se hizo el mejor modelo de la Poesía Española. Don Diego de Mendoza, uniendo en su elevado entendimiento la pureza y elocuencia de Livio con la fuerza y gravedad de Salustio, dio el estilo en sus Guerras de Granada a los grandes historiadores que después le siguieron y adelantó un gran trecho los límites de la lengua castellana. El aragonés Gonzalo Pérez, Secretario del Emperador Carlos V, en sus traducciones españolas de las obras de Homero mostró bien la riqueza de nuestra lengua, que era capaz de tener a Homero hecho español, pero tan grande y tan elegante como griego, a lo que hasta entonces no se había atrevido ninguna otra lengua vulgar. Iba ella creciendo entre tan ilustres ingenios y volando hacia la más encumbrada perfección. Pero aún quedaba que hacer. Se le había de dar mayor dulzura y fuerza para que se hallase del todo agradable y varonil. Se había de librar del todo de algunos resabios antiguos como de repetición de letras [...], concurrencia de consonantes ásperas [...], pronunciaciones difíciles [...], librarla de los apóstrofes inútiles [...], limpiarla en algunas palabras aún toscas [...]. Todo esto se consiguió, y mucho más, por la erudición vastísima y diligencia suma del Maestro Fr. Luis de Granada, quien entre todos el primero, con el don de la elocuencia que tuvo del cielo, dio fuerza, eficacia y natural dulzura al lenguaje español, pudiéndosele llamar con razón el Cicerón de nuestra lengua. No menos rico, dulce y puro se mostró en sus escritos espańoles el incomparable teólogo Benito Arias Montano, que supo manejar con tanto provecho de la religión el profundísimo conocimiento de lenguas, que se adquirió con tantos desvelos. 
Síguese luego el Maestro León, a quien estaba todavía reservado el nuevo y no usado camino de escribir en nuestra lengua poniendo en ella número y levantándola del descaimiento ordinario. A cuyo fin pesó las palabras, miró su sonido y las ordenó en su lugar con el debido concierto, para henchirla no solo de claridad, sino también de armonía y dulzura, y con esto llegó desde entonces nuestra lengua a igualarse aun en esta virtud con las mejores, a las cuales vence ella, a juicio de este admirable varón, en otras muchas virtudes.

Animados con estos grandes ejemplares de gravedad y elocuencia espańola, otros grandes ingenios siguieron este rumbo, y salieron en ella maestros perfectos el gran político Antonio Pérez, Secretario de Felipe II, el Bachiller Pedro Rúa, Don Antonio Agustín, Pedro Mexía, Gonzalo de Illescas, el P. Juan de Mariana, Miguel de Cervantes, Fr. Hernando del Castillo, D. Alonso de Ercilla, Juan Rufo, los Herreras y los dos hermanos Argensolas, con otros muchos que florecieron en estos tiempos. Todos estos no se contentaron con enriquecer a la lengua patria con lo más florido y ameno de la toscana, sino también con lo más precioso y elegante de la latina, y con lo mejor, más grave y eficaz de la griega, como lo muestran sus grandes obras, que debemos respetar como modelos del todo acabados para nuestra imitación y enseñanza [...]. [pp. 81-85]

Capítulo VII. Época IV de la Lengua Española. Su decadencia. Desde Felipe II hasta Felipe V.

[...] Pueden compararse con aquellos primeros Padres de nuestra lengua muchos de los que florecieron al principio de esta época, como el P. Ribadeneyra, puro y elegante; Luis Muñoz, suave, casto y eficaz; Antonio de Herrera, grande y elevado; el Maestro Fr. Juan Márquez, muy benemérito de la dulzura castellana; Mateo Alemán, de valiente y noble estilo; el Obispo Fr. Pedro de Ońa, y Don Diego de Saavedra, acabados en el arte de bien hablar y adornados de todos los primores de la lengua.

A los poetas les debemos mucho agradecimiento, pues no solo conservaron la elegancia de la lengua patria entre sus armoniosas consonancias al principio del siglo, si que, logrando en Felipe IV un soberano amante de la Poesía, la sostuvieron por algunos ańos en medio de la decadencia general de los demás escritores; aunque a la fin ellos fueron los que más la afearon. Son dignos de los elogios de la posteridad Lope de Vega, erudito en todas letras y ciencias, a quien las Musas estuvieron siempre prontas para inspirarle todas sus gracias, y aunque no es igual en todas sus obras, porque escribió tantas, sin embargo se puede intitular el Ovidio Español; del mismo modo que Esteban Manuel de Villegas, el Anacreonte Castellano por su dulzura y suavidad; Don Francisco de Borja, Príncipe de Esquilache, y de las letras, el más ajustado de todos a las leyes y rigor de su arte, en medio de su naturalidad y feliz vena. Compitieron con los primeros Maestros de nuestra Poesía D. Juan de Jáuregui y Francisco López de Zárate.

En Don Luis de Góngora renació un Marcial, pero su extremada agudeza le 
hizo demasiado obscuro, y su excesiva graciosidad le dio ocasión de jugar de la lengua castellana con tantos equívocos y donaires, que parece la ultrajó en su gravedad y decoro, de que ella tanto se precia; y con esto dio ocasión a otros de ingenio muy inferior al uso desmedido de juegos y graciosidades, de arte que finalmente nos la dejaron vana y aun ridícula. Pecó también Quevedo, y aun acaso con más exceso que Góngora, de igual ingenio, de vastísima erudición, profundo estudio de lenguas, y gran conocedor del precio y excelencias de nuestro romance y de los vicios con que ya lo habían entonces inficionado aun aquellos que se gloriaban de más cultos; los que notó graciosamente en su Culta-Latini-Parla y Cuento de Cuentos. Omito otros poetas clásicos como Don Antonio de Mendoza, el Maestro Valdivieso, Anastasio Pantaleón, dignos de veneración, y los maestros de la Cómica Don Pedro Calderón, Moreto, Solís, Montalbán, Don Francisco de Rojas, que se acomodaron en adelante al mal gusto del siglo. Otros de la misma facultad, pero faltos de vena y más de erudición, afectando conceptos sutiles y equívocos de palabras, cuando se figuraron al torrente del vulgo grandes artífices de la Poesía, eran verdaderos fantasmas con detrimento grave de la buena locución y sólida elocuencia. No he hecho mención antes de Fr. Hortensio Feliz Paravicino: sus méritos para con el habla castellana son de primer orden y ocupan un lugar muy principal, porque se adquirió el lenguaje tan armonioso, facundo y elegante, que halagaba los oídos su prosa tanto como el verso. Pero esta virtud en él ocasionó la mayor caída en la lengua y mayores vicios en otros que le quisieron imitar, porque los oídos que llegaron a sentir la suavidad del número se hicieron soberbios y no se contentaron en los oradores con cláusulas de menor artificio. Mas ¿quién, de los que le remedaron, se comparará con él en ingenio, en doctrina y en aplicación? Inventaron nuevas voces para llenar los vacíos de sus cláusulas, desfiguraron las antiguas y castizas, latinizaron el romance y romanzaron el latín. El que decía, sólo se aplicaba a detener el oído con la armonía de las voces; el que oía, aunque no formaba idea alguna, quedaba divertido con aquella extraña música. Todos se mostraban muy satisfechos, y el mal se hacía más incurable. [pp. 87-90]

4) Agustín de San Juan Bautista, Gramática de la Lengua Latina... nuevamente dispuesta e ilustrada a uso de las Escuelas, Valencia, Benito Monfort, 1769.

Como en esta clase [de Humanidad] han de tomar más bien el conocimiento del latín por el gusto de la Poesía, traducirán principalmente los poetas como los Metamorphoseos de Ovidio (para aprender también la Mitología, fundamento de la Poesía, como la Historia lo es de la Retórica), Bucólicas y Eneida de Virgilio, Lucano, Odas de Horacio, etc. Harase principal uso del Monumenta salutis de Arias Montano, porque forma el gusto de la Poesía con tanta destreza como el mismo Horacio, y con la ventaja de contenerse en este los hechos más admirables de nuestra Santa Religión con su propria sencillez y majestad; esperamos darlo también en verso castellano, para que lo puedan decorar los nińos, por lo mucho que importa. Se unirá a la de estos autores la lección de los poetas castellanos, 
especialmente los de un mismo género de Poesía, como a Garcilaso con Virgilio, a León con Horacio, a Ercilla con Lucano, a Lope de Vega y Villegas con Ovidio, y también carear las piezas traducidas por nuestros poetas espańoles con los originales latinos, v. gr. las Odas de Horacio con la traducción de León o Villegas, el Arte poética con la de Espinel, las Sátiras con los Argensolas o con el Príncipe de Esquilache. Aprenderán las especies más comunes de la poesía latina, y también de la espańola, más por la explicación de buenos poetas que por serie de reglas.

Notarán asimismo con puntual diligencia la diferencia entre el verso y la prosa, no solo en cuanto a las expresiones, sino principalmente en cuanto a las imágenes, adornos y pensamientos. Esta diferencia la entenderán mejor por las poesías del romance, a cuyo efecto se han dispuesto a uso de las Escuelas dos colecciones que comprenden las piezas más elegantes, así sagradas como profanas, de nuestros grandes poetas ${ }^{58}$. Un año bien cumplido se debe emplear en los ejercicios de esta clase para un adelantamiento decente. Al fin de la clase, harán componer a los niños alguna oda, epigrama u elegía, y también algunas décimas, redondillas, octavas, romances, etc., pero con $\mathrm{pa}[\mathrm{r}]$ simonia, según las muestras de ingenio que ofrezcan los discípulos.

Al cuarto ańo se ejercitarán seńaladamente en lo perteneciente a la clase de Retórica [...]. Los preceptos sean muy breves, y si a este fin decoran los niños el Arte Poética de Horacio, cogerán mucho fruto, especialmente en cuanto a las leyes de Invención, Disposición y Elocución. Se podrá también aprender de memoria el Arte Crítica de Pope, puesta en verso castellano y acomodado a nuestros autores y usos, y asimismo leer con cuidado la Retórica Española de D. Gregorio Mayans.

Se han de traducir con diligencia algunas oraciones de Cicerón, pues en cualquiera de ellas, que deberán decorar, observarán más bien las reglas que en todas las Retóricas juntas. Puede elegirse alguna con la traducción de Abril en romance. Las Arengas de Livio, Salustio, Curcio y Tácito, por ser breves, son más adaptables a la capacidad de los estudiantes, y si al mismo tiempo hacen cotejo con algunas españolas de Mendoza en las Guerras de Granada, de Mariana en la Historia de España, de Solís en la Conquista de Méjico, se conseguirá todo el aprovechamiento de dar a conocer el artificio retórico. También se podrá cotejar con el Panegírico de Plinio algún sermón de Fr. Hernando de Santiago o de Fr. Félix Hortensio; de aquí se harán algunas observaciones sobre la elocuencia del púlpito y de los tribunales que en el día necesitamos.

Léase de nuevo la Eneida de Virgilio, y se pueden proponer algunos lugares con la traducción en romance de Gregorio Hernández. Los Libros De Officiis de Cicerón abrazan gran parte de las obligaciones que tenemos en la sociedad humana, y son utilísimos para esta clase. Los extranjeros explican en esta Aula los Diálogos de Medallas de nuestro D. Antonio Agustín, que son muy a propósito para el estudio de la Antigüedad y de la Historia. Continúese alguna composición

58. Vicente Faubell Zapata reconoce no haber podido ver ninguna de estas dos antologías (op. cit., p. 491); tampoco he conseguido localizarlas -o identificarlas- en fuentes bibliográficas más actualizadas, como, por ejemplo, el Catálogo Colectivo del Patrimonio Bibliográfico. 
en verso de ambas lenguas, como también alguna arenga breve, o cria de asunto fácil, según la edad y progresos de los discípulos. Estos ejercicios, para los días de aula. [«Del método y uso de esta Gramática. Al letor», h. 6r-7r]

5) 1781 [Primera edición, no consultada, de:] Andrés Merino de Jesucristo, Breve tratado de poesía latina y castellana, dispuesto para uso del Real Seminario de Escuelas Pías de San Antonio Abad de esta Corte... Segunda edición, Madrid, Repullés, 1818.

$P$. ¿Tenemos en castellano algún poema épico?

$R$. No, señor, pues aunque muchos han querido que los sean la Araucana de Ercilla, la Jerusalén conquistada de Lope de Vega y el Bernardo de Valbuena, no pueden apropiarse este honroso título, como puede ver cualquiera que quiera aplicar las reglas que llevamos dichas de estas composiciones; algo más lo merecen Las Naves de Cortés destruidas, de Moratín, y La inocencia perdida, de Reinoso, pero ambas composiciones modernas no son más que unos ensayos que sus autores hicieron para demostrar prácticamente que sabían en qué consistía la naturaleza del Poema, y es lástima que su ingenio no se hubiera ensayado en composición más extensa para que nuestra lengua no careciera de la mayor que reconoce la Poesía. [pp. 27-28]

$P$. ¿Qué me decís de las composiciones líricas de nuestro Parnaso?

$R$. Que en este género puede competir no solo con el de las naciones más cultas de Europa, sino también con lo mejor que nos ha quedado de los griegos y romanos.

$P$. ¿Y qué autores deberemos proponernos por modelo?

$R$. Después que se restauraron en Italia las bellas letras y sus luces iluminaron el hemisferio español, aparecieron algunos poetas cuya dulzura, belleza y propiedad puede asegurarse que encantaron a las mismas Musas, las que si hubieran de haber hablado en español, no hubieran seguramente usado de otro lenguaje. Garcilaso es admirable por su suavidad, el Maestro León por su gravedad verdaderamente horaciana, Herrera por su elevación y grandiosidad en el lenguaje poético, los dos hermanos Argensolas por su madurez y castizo lenguaje, y algunos otros más, cuyas composiciones deben proponerse por modelo los que, con el talento necesario, quieran dedicarse al embeleso de la poesía española.

$P$. ¿Y qué me decís de los poetas de nuestros días?

$R$. Sabida cosa es que en el reinado de Felipe IV comenzó a decaer la facultad poética, y tanto que vino a parar en una algarabía pedantesca de conceptillos falsos, equívocos, antítesis ridículas y cosas semejantes; así como la majestad de la arquitectura practicada por Herrera vino a declinar en el gusto depravado de Churriguera. En el siglo que acaba de pasar [siglo XVIII], volvió a restaurarse segunda vez por sujetos que modelaron sus composiciones, tanto por los buenos autores de la antigüedad griega y romana, como por los del siglo XVI que los 
habían imitado. Cadahalso, González, Moratín, Reinoso, Meléndez y algunos otros templaron sus instrumentos tan diestramente, que no han dejado de admirar a los sabios; pero para nuestra instrucción debemos saber que muchos, sin las luces de estos, que han querido meterse en este coro sin ser llamados, han compuesto versos fríos, lánguidos, desaliñados y tan despreciables, que, a pesar de haberse dado a la prensa, servirán solo, o para envolver especias, o para servir de pasto a la polilla en las bibliotecas. [pp. 61-63]

6) Juan Cayetano Losada, Elementos de Poética extractados de los mejores AA. [autores] e ilustrados con ejemplos latinos y castellanos, y un apéndice sobre las especies de versos más comunes en nuestra lengua, Madrid, Viuda e hijo de Marín, 1799.

¿Cuáles fueron sus principios y progresos [de la Poesía] entre los españoles?

La misma suerte que corrió en la Grecia e Italia la Poesía, tuvo en Espańa. Es probable comenzase con la misma lengua castellana, si bien muy tosca, como en las demás naciones, puesto que en todas se canta, y el canto pide de sí la armonía del verso; igualmente, los primeros versos es de creer se harían imitando el ritmo latino y la poesía de los árabes espańoles, que fueron los que conservaron algunas artes. El constar los versos más antiguos de diez y seis, catorce y doce sílabas, si bien también se encuentran de ocho y de seis, manifiestan su origen. Esta clase de versos se encuentran, aunque muy toscos, hasta los años 1450, que comenzó a perfeccionarla algún tanto Juan de Mena y algunos otros poetas castellanos, pero por los ańos 1550 empezó a cultivarse con verdadero gusto. Desde esta época introdujeron los versos italianos de once y de siete sílabas, solos y mezclados, Boscán, Garcilaso, llamado el Príncipe de la Lírica española, Don Diego de Mendoza y Castillejo, habiendo seguido sus pasos con rápidos progresos Fr. Luis de León, Luis Barahona de Soto, Espinel, Ercilla, Figueroa, Lope de Vega, los Argensolas, Don Manuel Esteban de Villegas, Rojas, Rebolledo, Jáuregui, Villaviciosa, y otros varios que ilustraron y perfeccionaron la Poesía hasta principios del siglo decimoséptimo, pudiéndose llamar aquella la edad de oro de la Poesía en España, pues no tenía que envidiar nada nuestra nación a lo más bello de las extranjeras. Pero así como la Italia y Francia comenzaron a decaer del buen gusto de la bella Poesía, así también pegaron el contagio a nuestra nación, degenerando toda la majestad y grandeza a que la habían elevado aquellos ingenios en una hinchazón fastidiosa e ininteligible y en un afectadísimo artificio. A esta corrupción contribuyó no poco Don Luis de Góngora, que si bien era un poeta ingenioso, dotado de viva fantasía y numen poético, como lo demuestran sus excelentes letrillas, sátiras y poesías burlescas, su ansia de sobresalir a los antiguos le hizo caer en el defecto de hacer gala de retruecanillos, antítesis, equívocos, ridículas hipérboles y trasposiciones, y metáforas atrevidas, con que abrió camino a un estilo pomposo y despreciable que siguieron otros muchos en toda clase de poesía, pero especialmente en la dramática, llevados de la novedad y aplauso del vulgo, que alaba por grande y sublime lo que no entiende. Así se introdujo la corrupción 


\section{BULLETIN HISPANIQUE}

y desprecio de las reglas del arte, que por tantos tiempos ha durado, anhelando la mayor parte de nuestros poetas a imitar los dislates de Góngora, Lope de Vega y Calderón, y aventajarse a ellos en los yerros, sin acercarse con infinita distancia en sus aciertos, y de esta suerte ocasionaron la última ruina a la Poesía, hasta que en estos últimos tiempos, renaciendo el gusto de leer e imitar a los antiguos latinos, griegos y nuestros buenos castellanos, único método para que florezcan las Bellas Letras, vemos revivir la Poesía con nuevo lustre en todas sus especies en un Ayala, los Moratines, Iriarte, Samaniego, Fr. Diego González, Meléndez y algunos otros. [pp. 6-8] 